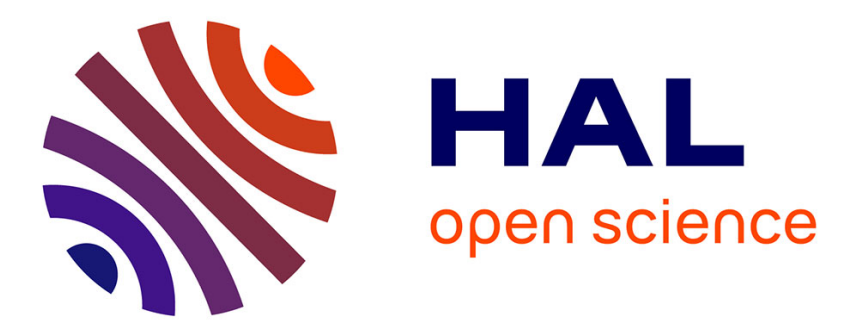

\title{
Lichens as natural sources of biotechnologically relevant bacteria
}

Marcelino T. Suzuki, Delphine Parrot, Gabriele Berg, Martin Grube, Sophie Tomasi

\section{- To cite this version:}

Marcelino T. Suzuki, Delphine Parrot, Gabriele Berg, Martin Grube, Sophie Tomasi. Lichens as natural sources of biotechnologically relevant bacteria. Applied Microbiology and Biotechnology, 2016, 100 (2), pp.583-595. 10.1007/s00253-015-7114-z . hal-01227960

\section{HAL Id: hal-01227960 https://hal.sorbonne-universite.fr/hal-01227960}

Submitted on 12 Nov 2015

HAL is a multi-disciplinary open access archive for the deposit and dissemination of scientific research documents, whether they are published or not. The documents may come from teaching and research institutions in France or abroad, or from public or private research centers.
L'archive ouverte pluridisciplinaire HAL, est destinée au dépôt et à la diffusion de documents scientifiques de niveau recherche, publiés ou non, émanant des établissements d'enseignement et de recherche français ou étrangers, des laboratoires publics ou privés. 


\section{Lichens as natural sources of biotechnologically relevant Bacteria}

Marcelino T. SUZUKI ${ }^{*}$, Delphine PARROT ${ }^{2}$, Gabriele BERG $^{3}$, Martin GRUBE ${ }^{4}$, Sophie TOMASI $^{2}$

${ }^{1}$ Sorbonne Universités, UPMC Univ. Paris 06, CNRS, Laboratoire de Biodiversité et Biotechnologie Microbiennes (LBBM), Observatoire Océanologique, F-66650 Banyuls/Mer, France

${ }^{2}$ UMR CNRS 6226, Institut des Sciences chimiques de Rennes, Equipe PNSCM "Produits Naturels - Synthèses - Chimie Médicinale”, UFR Sciences Pharmaceutiques et Biologiques, Univ. Rennes 1, Université Européenne de Bretagne, 2 Avenue du Pr. Léon Bernard, F-35043 Rennes, France

${ }^{3}$ Institute of Environmental Biotechnology, Graz University of Technology, Petersgasse 12, 8010 Graz, Austria.

${ }^{4}$ Institute of Plant Sciences, University of Graz, Holteigasse 6, Austria

* Corresponding author. Tel.: +33 (0) 430192401

E-mail address: suzuki@obs-banyuls.fr (M.T. Suzuki) 


\begin{abstract}
The search for microorganisms from novel sources and in particular microbial symbioses represents a promising approach in biotechnology. In this context lichens have increasingly become subject of research in microbial biotechnology, particularly after the recognition that a diverse community of bacteria other than cyanobacteria are additional partners to the traditionally recognized algae-fungus mutualism. Here we review recent studies using culturedependent as well as culture-independent approaches showing that lichens can harbor diverse bacterial families known for the production of compounds of biotechnological interest and that several microorganisms isolated from lichens, in particular Actinobacteria and Cyanobacteria, can produce a number of bioactive compounds, many with biotechnological potential.
\end{abstract}

Keywords: lichens - bacteria - Actinobacteria - Cyanobacteria- biotechnology. 


\section{Introduction}

Recently, the World Health Organization (WHO) produced a global map of antimicrobial resistance and issued a warning that a 'post-antibiotic' world could soon become a reality and has already started (Woolhouse and Farrar 2014). Therefore, the quest for new drugs from microbial sources is currently at a crossroads, where on one hand it is widely thought that the discovery of novel compounds has passed its "golden era" with many pharmaceutical companies abandoning or downscaling their microbial natural products research, while on the other hand, full genomic sequencing and metagenomic research shows that a large number of "silent" or novel biosynthetic pathways exist (for reviews see Brady et al. 2009 ; Ochi and Hosaka 2013), promising to lead to novel bioactive compounds produced via heterologous expression (e.g. Chang and Brady 2013). The continued search for microorganisms from novel sources represents an effective strategy forward towards drug discovery. In this context microbial symbioses are of particular interest, since increasing evidence supports the hypothesis that microbial bioactive compounds, such as those used as antibiotics, might be involved in microbe-microbe and microbe-host communication (Yim et al. 2007; Yoon and Nodwell 2014). An example supporting this hypothesis, is the fact that many interesting novel bioactive compounds of microbial origin have been discovered in marine sponges, known to harbor complex symbiotic microbial communities (see Fuerst 2014 for a review).

Lichens are a well-recognized, self-supporting, mutualistic symbiosis between a dominant fungal partner (mycobiont) that provides shelter for one or several photosynthetic green algae and/or cyanobacteria (photobionts) forming a unique symbiotic structure, the lichen thallus, (De Bary 1879; Frank 1876; Schendener 1860 reviewed in Honegger 2000). Lichen-forming fungi have evolved for at least 400 million years (Taylor et al. 1995). The lichen thallus is well-adapted to a wide variety of specific ecological niches, often including extreme environmental conditions (e.g. extreme temperatures, periodic desiccation, high levels of UV radiation). At least some of the mechanisms to cope with these extreme conditions are of a chemical nature (e.g. UV screens, cryoprotectants, osmolites) providing leads and inspiration for biotechnological development. It also appears that allelopathic compounds by the holobiont could play a role in the persistence of lichens. Despite estimated individual ages of decades to centuries, there are no reports of destructive bacterial infections in lichens. The capacity of produce a broad range of interesting chemical compounds help explain the fact, that lichens have been historically also used as sources of pigments, perfumes, human medicines etc. (Rikkinen 1995). 
A number of chemical structures have consistently been associated with lichens and due to their presence in axenic culture or other non-lichenizing fungi, it is generally accepted that they are produced by the mycobiont. Those include repeats of aromatic acids such as orsellinic acid (depsides, depsidones and usnic acids) that are believed to be synthesized by non-reducing fungal polyketide synthases (Huneck and Yoshimura 1996; Robinson 1999), that have been directly recovered from lichens (i.e. Grube and Blaha 2003; Muggia and Grube 2010 ; Schmitt et al. 2008). The diversity of these major compounds have been subject of recent reviews and catalogues (Boustie and Grube 2005; Elix 2014; Molnár and Farkas 2010; Shrestha and St Clair 2013; Shukla et al. 2010; Stocker-Woergoetter 2008) and therefore we will focus here on those produced by other microorganisms, in particular Bacteria, although we cannot rule out that these bacteria can be also involved in the biosynthesis or conversion of major compounds found in lichens.

\section{Culturable bacteria of biotechnological interest}

While the presence of microorganisms other than the mycobiont and the photobiont in the lichen holobiont has long been known by isolation techniques (Uphof 1925; reviewed in Cardinale et al. 2006), systematic attempts to study these organisms have only recently been carried out. One early study (Gonzalez et al. 2005) published 10 years ago clearly demonstrated that lichens are sources of bioactive microorganisms. That study focused on Actinobacteria by employing a targeted isolation strategy using nalidixic acid (an inhibitor of Gram-negative bacteria) as well as heat-treatment prior to cultivation. A standard medium (Yeast Malt Extract) was used for isolation from 25 terrestrial lichen samples from Hawaii, Alaska and the Reunion Islands. The lichens species were not identified and the samples were just classified as saxicolous (i.e. rock associated; 6 from Alaska, 5 from Hawaii) or arboricolous (i.e tree-associated; 5 from Hawaii and 9 from the Reunion Islands). A large number (337) of strains were obtained, and identified based on DNA fingerprinting and fatty acid analysis. Among these strains, 110 belonged to the family Streptomycetaceae, wellknown to produce bioactive compounds. Other actinobacterial families also know for the production of bioactive compounds, some belonging to the "rare Actinomycetes" sensu Subramani and Aalbersberg (2013), such as Micromonosporaceae (142 strains), Pseudonocardiaceae (30 strains) and Thermomonosporaceae (7 strains) were also isolated. These strains were screened for genetic potential for biosynthesis (PCR targeting genes 
involved in polyketide, small peptides, and isoprenoid biosynthesis), as well as antimicrobial activity (against Escherichia coli, Staphylococcus aureus and Candida albicans). A high percentage of strains (over 60\%) potentially contained at least one biosynthetic cluster and about $30 \%$ of the strains had antimicrobial activity against at least one of the target microorganisms.

Since the pioneering study by Gonzalez and colleagues (2005), many other studies have focused on lichen-associated bacteria via cultivation. A number of these studies have targeted individual isolates or species, especially for taxonomic purposes or for full genomic sequencing (Table 1). A particular interest was given to biotechnological potential of strains, since in several cases isolation selected for Actinobacteria by nalidixic acid addition ( 9 out of 23 strains). Finally in some cases [Actinoplanes sp. ATCC55532 (Singh et al. 1997), Streptomyces uncialis (Davies et al. 2005), Streptomyces sp. (Motohashi et al. 2010), S. cyaneofuscatus (Brana et al. 2015) and Streptomyces sp. (Lavallee 2011)] the focus was primarily on the discovery of novel bioactive molecules, with the first strain described in a patent (Singh et al. 1997). These strains will be discussed in a later section. It is remarkable that in several of these studies there is only a poor description or a complete lack of identification of the source lichens.

A different class of culture-based studies performed a more comprehensive isolation of lichen associated bacteria, basing the isolation on criteria other than bioactivity and, except for our recent study (Parrot et al. 2015), did not target Actinobacteria (Table 2). The results of these studies offer a less biased view of the cultivable bacterial diversity associated with lichens, and it is clear that certain bacterial phyla and classes, in particular Alpha- and Gammaproteobacteria, Firmicutes and Actinobacteria are frequently isolated from lichens (Cardinale et al. 2006; Grube et al. 2009; Selbmann et al. 2010). In addition Bacteroidetes seem to be isolated from marine or littoral lichens (Parrot et al. 2015; Sigurbjornsdottir et al. 2014). Among all isolates, many belong to bacterial families known to contain strains know to produce bioactive compounds, enzymes of biotechnological interest such as lipases proteases and antagonistic molecules (Table 2). In a few cases this was experimentally tested (Grube et al. 2009; Lee et al. 2014), while in others studies this potential was inferred by the presence of genes involved in the biosynthesis of polyketides or $16 \mathrm{~S}$ rRNA similarity to known bioactive strains (Parrot et al. 2015). In the latter study the authors focused on the isolation of Actinobacteria from marine and littoral lichens, and showed that these lichens were sources of bacteria of biotechnological interest, and that the use of Marine Agar, a medium used to the 
isolation of a broad diversity of marine bacteria, yielded many strains that were not recovered with the commonly used Actinomycete Isolation Agar medium, and this did not appear to be an effect of salinity (Parrot et al. 2015). Among these stains some appeared to represent novel species or even genera. Finally that study compared the 16S rRNA genes to those in the NCBI Genbank from bacteria associated with lichens studied using culture independent methods and as expected none of the strains appeared to be prevalent in the studied lichens.

To obtain a larger representation of lichen associated strains, including strains for which only 16S rRNA sequences exist, we searched all 16S rRNA gene sequences present in the NCBI Genbank nt database with the query "lichen AND bacteria [orgn] NOT Cyanobacteria [orgn] NOT uncultured" and recovered the taxonomy information associated with these sequences (associated or not to publications), and obtained somewhat similar results, which again might be a reflection of the targeting of Actinobacteria in isolation efforts even though this analysis did not include the study of Gonzalez and colleagues and Parrot and colleagues that have focused on Actinobacteria (Gonzalez et al. 2005; Parrot et al. 2015). Among 511 bacterial strains retrieved, nearly half of isolates (246) belong to Actinobacteria, 185 to Alphaproteobacteria, 85 to Firmicutes and 59 to the Gammaproteobacteria. Focusing on bacterial families of biotechnological interest, about 30\% (150 in 511) belong to the families Bacillaceae (40), Paenibacillaceae (37), Burkholderiaceae (24), Pseudomonadaceae (19), Streptomycetaceae (18), Micromonosporaceae (5), Nocardioidaceae (5) and Pseudonocardiaceae (2) known for the production of bioactive molecules.

Finally, a number of studies have attempted to cultivate cyanobacteria (mostly the main photobionts) from lichens (Table 3). In addition to the search of bioactive compounds of pharmacological the main interest a few of these studies was the production of toxins or other metabolites by these cyanobacteria strains, and in particular hepatoxins relevant to public health (see Dittmann et al. 2013 for a review). Extensive genetic and chemical screening of lichens of the lichen order Peltigerales, known of for their association with the cyanobacterial genus Nostoc have clearly shown that a non-negligible (about $5 \%$ of specimens) contain microcystins or nodularins (Kaasalainen et al. 2013) most likely produced by symbiotic cyanobacteria. In addition to the original interest for public health, the use of microcystin congeners has also recently been proposed for cancer therapy (Niedermeyer et al. 2014), demonstrating the interest in these lichen associated cyanobacteria. 
Summarizing, existing information from culture-based studies clearly show that lichens can be a source of bacterial strains of biotechnological interest such as Bacillus, Paenibacillus, Pseudomonas, Burkholderia and Nostoc. Regarding Actinobacteria, interesting strains in this phylum were isolated even without selective approaches. Studies using selective approaches yielded a higher diversity of Actinobacteria and in particular of non-Streptomyces genera, including possible new species. It also appears that cyanobacterial symbionts can be a promising source of bioactive molecules of biotechnological interest.

\section{Strains known to produce bioactive compounds}

Despite the large number of bacterial strains of relevance to drug discovery isolated from lichens, the presence of structurally-identified bioactive molecules have only been reported for a few of these strains (Streptomyces uncialis and Actinoplanes sp. ATCC55532, Streptomyces sp. RI104-LiC106, Streptomyces sp. RI104-LiB101, Streptomyces sp. L-91-3 Nostoc sp., Nostoc sp. ATCC 53789 and Nostoc sp. IO-102-I Tables 1 and 3). In addition, identified molecular structures have also been reported for strain S. cyaneofuscatus T178 reported as being phenotypically and metabolically indistinguishable from $S$. cyaneofuscatus M-27. The relative small number of reported molecules is partly due to the fact that interest in lichen-associated bacteria is relatively recent but also likely due to the fact that publications tend to focus on novel chemical structures, and thus presence of known compounds, even in novel organisms, is seldom reported. In the following paragraphs we describe several lichenassociated bacteria for which bioactive compounds have been identified. The molecular structures of selected compounds are presented in Figure 1.

Actinoplanes sp. ATCC55532 was isolated from a non-identified arboricolous lichen from Spain has been reported to produce actinoplanic acids A and B (Singh et al. 1997). This patent also claims that actinoplanic acid B (1) inhibits farnesyl-protein transferase (FPTase) and the farnesylation of the oncogene protein Ras, in vitro at ( $\mathrm{IC}_{50}$ at $\left.50 \mathrm{nM}\right)$ and thus have a potential for the treatment of colorectal carcinoma, exocrine pancreatic carcinoma and myeloid leukemias.

Streptomyces uncialis, isolated by Davies and co-workers from a Cladonia uncialis, has been the been well characterized and reported to produce the enediyne antibiotic uncialamycin (2) highly active against Escherichia coli, Staphylococcus aureus as well as 
Burkholderia cepacia (Davies et al. 2005). The same strain produces the alkaloids Cladoniamides A-G with the latter (3) showing significant in vitro toxicity against MCF-7 breast cancer cells at $10 \mu \mathrm{g} / \mathrm{mL}$ (Williams et al. 2008). A second lichen-derived Streptomyces strain isolated from lichens by the Davies' group (L-91-3) was reported to produce several inhibitors of Catepsin K (a protease identified as a drug target for osteoporosis therapy Yasuda et al. 2005). These molecules included the oligopeptide Antipain and two analogues described as vince-2 and lichostatinal (Lavallee 2011).

Strains RI104-LiC106 and RI104-LiB101 reported as belonging to a new Streptomyces species have been shown to produce JBIR-88 (4), a 1,1-dichlorocyclopropane-containing angucycline and JBIR-89 (5), a butenolide. JBIR-88 was cytotoxic to HeLa and ACC-MESO1 cells IC50 36 and $52 \mathrm{mM}$, respectively. It also showed antibacterial activity against Micrococcus luteus, but not against Candida albicans and E. coli (Motohashi et al. 2010).

S. cyaneofuscatus M-27 was isolated from the algae Fucus spiralis and reported to be metabolically indistinguishable from S. cyaneofuscatus T-178 isolated from an unidentified lichen. This strain was reported to produce a number of anthracycline family antitumor antibiotics daunorubicin, cosmomycin B (6) and galtamycin B and the antifungal macrolactam maltophilin (7). Daunorubicin is already used as a drug for cancer chemotherapy, cosmomycin B shows in vitro cytotoxicity against the KB human epidermoid carcinoma cell line (Ando et al. 1985) and galtamycin B shows in vitro cytotoxicity against gastric adenocarcinoma (HMO2), breast carcinoma (MCF7), and hepatocellular carcinoma (HepG) cell lines at (10 $\mu \mathrm{g} / \mathrm{mL}$ Antal et al. 2005). Maltophilin has been shown to inhibit the growth of a number of fungi (Jakobi et al. 1996). It has to be noted however that all molecules reported to be produced by $S$. cyaneofuscatus M-27 were only identified based on their HPLC retention time and UV-vis spectra (Brana et al. 2015).

Nostoc strain. ATCC 53789 was isolated from lichens and was shown to produce cryptophycin 1 (8), which was originally patented for its antifungal properties (Moore and Patterson 1997). Further analysis of other molecules in this class resulted in the discovery of it biosynthetic pathway, and of a strategy for chemoenzymatic synthesis of analogous molecules (Magarvey et al. 2006), Furthermore, a synthetic analog (cryptophycin 52) achieved Phase II clinical trials for lung cancer therapy (Edelman et al. 2003) at which stage development was stopped. More recently, the use of cryptophycin analogs in antibody-drug conjugates has also been proposed (Verma et al. 2012). 
An unnamed Nostoc sp. strain isolated from Peltigera canina was shown to produce the chlorine containing nostoclides I and II, which have moderate toxicity $(10 \mu \mathrm{g} / \mathrm{ml})$ against cell lines Neuro-Pa CCL 131 and KB CCL17. Nostoc sp. strain IO-102-I isolated from a Pannaria pezizoides from Finland, appears in turn to be the only lichen-derived isolate shown to produce a number of microcystins (Oksanen et al. 2004), despite the report that many lichen specimens contain this class of molecules.

Finally, a recent study has reported that a Nostoc sp. strain N6 isolated from Peltigera membranaceae produces nosperin (9) a pederin like-molecule, produced by a predominantly trans-AT polyketide synthase biosynthetic pathway (Kampa et al. 2013). In this remarkable study Kampa and colleagues predicted - using shotgun metagenomic sequencing and sequence-based biosynthetic analysis - that a Nostoc strain was likely to produce a pederinlike molecule. Based in this information the authors were able to perform targeted isolation of the cyanobacterium that was followed by mass cultivation and isotopic incorporation to finally determine the structure of this molecule present in very low abundance, linking it to its most likely biosynthetic pathway (Kampa et al. 2013).

In summary, although interest in lichen-associated biotechnologically relevant bacteria is relatively recent, a number of bioactive and structurally identified molecules were produced by Actinomycetes and Cyanobacteria isolated from lichens, with some novel structures of high potential and some already in drug development.

\section{The yet untapped potential seen through cultivation independent approaches}

For the past 10 years, lichen-associated bacteria have been subject of an increasing number of cultivation-independent molecular surveys. These studies employed a number of techniques including fingerprinting of rRNA genes, fluorescence in situ hybridization and sequencing from mixed microbial populations (e.g., Cardinale et al. 2006, 2008, Grube et al. 2009). The cultivation-independent approaches used DGGE, SSCP, 16S rRNA gene cloning and Sanger sequencing, or next generation sequencing (454 pyrosequencing, Illumina sequencing) either of PCR amplified 16S rRNA genes or of shotgun fragments (Table 4). These studies clearly show a difference in abundance and diversity of culture-dependent versus -independent fractions of the lichen associated bacterial communities and demonstrated that the bacterial communities of most lichens studied so far are dominated by bacteria 
belonging to the Alphaproteobacteria class of the Proteobacteria, with other taxa such as the Beta-, Gamma- and Deltaproteobacteria and the phyla Bacteroidetes, Actinobacteria, Firmicutes and Verrucomicrobia frequently present (Grube et al. 2015). The general relationships between microbiomes, lichen morphology, photobiont and substrates have recently been summarized by Aschenbrenner and colleagues, indicate that most lichens do have Alphaproteobacteria as predominant symbionts, although at a finer taxonomic resolution some patterns emerge such as the importance of Acidobacteria and Acetobacteraceae (Rhodospirillales) in acid rock and soil lichens, and higher actinobacterial percentages in intertidal lichens (Aschenbrenner et al. 2014).

Even though lichens are hosts of phyla and classes known to contain species with potential of producing bioactive compounds, such as the Actinobacteria and Firmicutes, an analysis of diversity at a finer resolution indicates that although present, bacterial families of biotechnological interest (apart from the Cyanobacteria) are relatively minor members of the community, with the Burkholderiaceae and Paenibacillaceae representing at a maximum one percent of the community, while the other families are about 10 to 100 times less abundant (Table 4). That does not decrease the potential for biodiscovery based on cultivation approaches, as it has been clearly pointed out in the previous sections. However, lower relative abundances have to be taken in account when evaluating the role of these organisms and their bioactive molecules to the lichen symbiosis (i.e. their spatial localization and aggregation becomes important), and during the design of culture independent strategies to uncover the biotechnological potential of these microorganisms (i.e. via metagenomics).

One interesting point emerging from cultivation independent studies, is the presence Myxococcales in relative abundances of the same range or sometimes higher than those of Actinobacteria (Table 4). This group of microorganisms is particularly interesting with large genomes and potential to the production of bioactive compounds (Dworkin 2001). Myxobacteria have a particular life style (Dworkin 2001) which is also conducive to the use of targeted isolation (e.g. Zhang et al. 2003), but to date a single lichen-associated Myxobacteria [ATCC 25944 (M 155)] has been described (McCurdy 1971). This is interesting, since in the original description of the Myxobacteriaceae Thaxter indicates that a number of species including Corallococcus (Myxococcus) coralloides and Melittangium (Chondromyces) lichenicolus were associated with lichens (Thaxter 1892), and myxobacteria have been reported as associated to decaying lichens (Reichenbach 1999) . 
Regarding the application of metagenomic techniques in biotechnological development of lichen-associated bacteria, the nosperin example discussed above (Kampa et al. 2013) clearly shows that the direct shotgun sequencing and assembly and analysis of cyanobacterial genomes can lead to the discovery of potentially new novel interesting molecules and biosynthetic pathways, as well as guide targeted cultivation of microorganisms of interest. Other recent studies have applied shotgun sequencing targeting lichen associated bacteria (Grube et al. 2015; Sigurbjornsdottir et al. 2015), but the complexity of community did not allow the assembly of contigs long enough to permit analyses of biosynthetic pathways. A focus on lichens with chlorophyte symbionts, with a possible physical separation of bacteria (or bacterial DNA) would increase the chance of assembling larger genomic fragments and allow a better access to biosynthetic pathways, in particular those possibly present in the genomes of dominant Alphaproteobacteria symbionts (with the caveat that these organisms are not the most prolific in terms of the biosynthesis of bioactive molecules). Other techniques such as the construction and massive screening of fosmid libraries (e.g. Freeman et al. 2012) or single cell genomics (e.g. Wilson et al. 2014) likely represent better alternatives to access the genomes of rarer bacteria from lichens. However, the fact that many of the bacteria with biosynthetic potential present in lichens belong to groups for which targeted cultivation methods do exist, seem to indicate that for the near future, cultivation based-methods might be in fact a more promising approach.

In a first metaproteomic study, proteomics using one-dimensional gel electrophoresis combined with LC-MS/MS and normalized spectral counting was applied to characterize the active proteins of the Lobaria pulmonaria symbiosis (Schneider et al. 2011). Interestingly, not only the fungal partner was characterized by a rich secondary metabolism, also the bacterial partners showed a high activity supporting the hypothesis of biotechnologically relevant bacteria in symbioses.

\section{Further biotechnological potential of lichen-associated bacteria}

Irrespective of their capacity to produce small metabolites, lichen-associated bacteria have a wider biotechnological potential. According to a pioneering study by Gasser et al. (2011), one third of the detected lichen-associated bacteria have the potential to produce PHA biopolymers, yet, the strains isolated also showed a remarkable high antagonistic potential against plant pathogens. Up to $100 \%$ were antagonistic especially against leave pathogens, 
such as Alternaria alternata. Similarly, antagonistic properties were also detected by Kim et al. (2013, 2014). Cernava et al. (2015) studied the antagonistic potential of a lichen-associated bacterial community of the lung lichen (Lobaria pulmonaria) with an integrative approach combining isolate screening, multi-omics techniques and high resolution mass spectrometry. The highly diverse microbiome contained an abundant antagonistic community dominated by Stenotrophomonas, Pseudomonas and Burkholderia. In these examples, the precise principle of antagonisms, and whether this also comprises interesting novel compounds, still needs to be established. The examples for antagonisms will be continued with future studies, especially after Zachow et al. (2013) proposed a promising screening strategy using plant rhizospheres as bait for lichen-associated bacteria. These studies further support lichens as important reservoirs of bacteria that are biotechnologically attractive.

Considering the high estimate of 18500 described lichens, much work apparently lays ahead of us to exploit their biotechnological potential. A more focused search for the most promising habitats and species may be guided by ecological knowledge. This possibly includes habitats where microbial regulation and competition becomes a major factor due to certain abiotic parameters, such as temperature and water availability. Thus expected hot spots for further research will include warmer zones such as tropical rain forests, or those, which are more frequently exposed to water inundation, including water streams or intertidal habitats.

\section{Acknowledgments}

This work was partly supported by EMR, a partnership between the UPMC, the Laboratoires Pierre Fabre and CNRS and by the project MALICA (10-INBS-02-01) of the Agence Nationale de la Recherche, France, as well as by the Fonds zur Förderung der wissenschaftlichen Forschung (FWF I882), and the Wissenschaftlich-Technische Zusammenarbeit, Austria. We thank Sanjay Antony-Babu, Nyree West, Laurent Intertaglia for fruitful discussions and Scott T. Bates for sending OTU tables from his previous publication.

Conflict of Interest: The authors declare that they have no conflict of interest.

\section{References}

An S-Y, Xiao T, Yokota A (2008) Schumannella luteola gen. nov., sp nov., a novel genus of the family Microbacteriaceae. J Gen Appl Microbiol 54:253-258 doi:10.2323/jgam.54.253

An S-Y, Xiao T, Yokota A (2009) Leifsonia lichenia sp nov., isolated from lichen in Japan. J Gen Appl Microbiol 55:339-343 
Ando T, Hirayama K, Takahashi R, Horino I, Etoh Y, Morioka H, Shibai H, Murai A (1985) The Structures of Anthracycline Antibiotics, Cosmomycins A and B. Agr Biol Chem Tokyo 49:1207-1209 doi:10.1271/bbb1961.49.1207

Antal N, Fiedler HP, Stackebrandt E, Beil W, Stroch K, Zeeck A (2005) Retymicin, galtamycin $\mathrm{B}$, saquayamycin $\mathrm{Z}$ and ribofuranosyllumichrome, novel secondary metabolites from Micromonospora sp Tu 6368 - I. Taxonomy, fermentation, isolation and biological activities. J Antibiot 58:95-102

Aschenbrenner IA, Cardinale M, Berg G, Grube M (2014) Microbial cargo: do bacteria on symbiotic propagules reinforce the microbiome of lichens? Environ Microbiol 16:3743-3752 doi:10.1111/1462-2920.12658

Bates ST, Cropsey GWG, Caporaso JG, Knight R, Fierer N (2011) Bacterial Communities Associated with the Lichen Symbiosis. Appl Environ Microb 77:1309-1314 doi:10.1128/aem.02257-10

Bjelland T, Grube M, Hoem S, Jorgensen SL, Daae FL, Thorseth IH, Ovreas L (2011) Microbial metacommunities in the lichen-rock habitat. Environ Microbiol Rep 3:434442 doi:10.1111/j.1758-2229.2010.00206.x

Boustie J, Grube M (2005) Lichens, a promising source of bioactive secondary metabolites. Plant Gent Resour 3:273-287

Brady SF, Simmons L, Kim JH, Schmidt EW (2009) Metagenomic approaches to natural products from free-living and symbiotic organisms. Nat Prod Rep 26:1488-1503 doi:10.1039/b817078a

Brana AF, Fiedler H-P, Nava H, Gonzalez V, Sarmiento-Vizcaino A, Molina A, Acuna JL, Garcia LA, Blanco G (2015) Two Streptomyces species producing antibiotic, antitumor, and anti-inflammatory compounds are widespread among intertidal macroalgae and deep-sea coral reef invertebrates from the central Cantabrian sea. Microb Ecol 69:512-524 doi:10.1007/s00248-014-0508-0

Cardinale M, de Castro JV, Jr., Mueller H, Berg G, Grube M (2008) In situ analysis of the bacterial community associated with the reindeer lichen Cladonia arbuscula reveals predominance of Alphaproteobacteria. FEMS Microbiol Ecol 66:63-71 doi:10.1111/j.1574-6941.2008.00546.x

Cardinale M, Grube M, Berg G (2011) Frondihabitans cladoniiphilus sp nov., an actinobacterium of the family Microbacteriaceae isolated from lichen, and emended description of the genus Frondihabitans. Int J Syst Evol Micr 61:3033-3038 doi:10.1099/ijs.0.028324-0

Cardinale M, Grube M, Castro JV, Jr., Mueller H, Berg G (2012a) Bacterial taxa associated with the lung lichen Lobaria pulmonaria are differentially shaped by geography and habitat FEMS Microbiol Lett 329:111-115 doi:10.1111/j.1574-6968.2012.02508.x

Cardinale M, Puglia AM, Grube M (2006) Molecular analysis of lichen-associated bacterial communities. FEMS Microbiol Ecol 57:484-495 doi:10.1111/j.15746941.2006.00133.x

Cardinale M, Steinova J, Rabensteiner J, Berg G, Grube M (2012b) Age, sun and substrate: triggers of bacterial communities in lichens. Environ Microbiol Rep 4:23-28 doi:10.1111/j.1758-2229.2011.00272.x

Cardinale M, Vieira de Castro Jun. J, Müller H, Berg G, Grube M (2008) In situ analysis of the bacterial community associated with the reindeer lichen Cladonia arbuscula reveals predominance of Alphaproteobacteria. FEMS Microbiol Ecol 66: 63-71.

Cernava T, Aschenbrenner IA, Grube M, Liebminger S, Berg G (2015a) A novel assay for the detection of bioactive volatiles evaluated by screening of lichen-associated bacteria Front Microbiol 6 doi:10.3389/fmicb.2015.00398 
Cernava T, Mueller H, Aschenbrenner IA, Grube M, Berg G (2015b) Analyzing the antagonistic potential of the lichen microbiome against pathogens by bridging metagenomic with culture studies. Front Microbiol 6 doi:10.3389/fmicb.2015.00620

Chang F-Y, Brady SF (2013) Discovery of indolotryptoline antiproliferative agents by homology-guided metagenomic screening. Proc Natl Acad Sci U S A 110:2478-2483 doi:10.1073/pnas.1218073110

Davies J, Wang H, Taylor T, Warabi K, Huang XH, Andersen RJ (2005) Uncialamycin, a new enediyne antibiotic. Org Lett 7:5233-5236 doi:10.1021/ol052081f

De Bary A (1879) Die erscheinung der symbiose. Verlag von Karl J. Trübner,

Dittmann E, Fewer DP, Neilan BA (2013) Cyanobacterial toxins: biosynthetic routes and evolutionary roots. FEMS Microbiol Rev 37:23-43 doi:10.1111/j.15746976.2012.12000.x

Dworkin M (2001) Myxobacteria. In: eLS. John Wiley \& Sons, Ltd. doi:10.1002/9780470015902.a0020391

Edelman MJ, Gandara DR, Hausner P, Israel V, Thornton D, DeSanto J, Doyle LA (2003) Phase 2 study of cryptophycin 52 (LY355703) in patients previously treated with platinum based chemotherapy for advanced non-small cell lung cancer. Lung Cancer 39:197-199 doi:10.1016/s0169-5002(02)00511-1

Elix JA (2014) A Catalogue of Standardized Chromatographic Data and Biosynthetic Relationships for Lichen Substances. Third Edition, 3rd edn. Published by the author, Camberra

Esposito A, Ciccazzo S, Borruso L, Zerbe S, Daffonchio D, Brusetti L (2013) A Three-Scale Analysis of Bacterial Communities Involved in Rocks Colonization and Soil Formation in High Mountain Environments. Curr Microbiol 67:472-479 doi:10.1007/s00284-013-0391-9

Frank A (1876) Ueber die biologischen Verhältnisse des Thallus einiger Krustenflechten. In: Cohn F (ed) Beiträge zur Biologie der Pflanzen., vol 2. vol 2. JU Kern, Breslay, pp 123-200

Freeman MF, Gurgui C, Helf MJ, Morinaka BI, Uria AR, Oldham NJ, Sahl H-G, Matsunaga S, Piel J (2012) Metagenome Mining Reveals Polytheonamides as Posttranslationally Modified Ribosomal Peptides. Science 338:387-390 doi:10.1126/science.1226121

Fuerst JA (2014) Diversity and biotechnological potential of microorganisms associated with marine sponges. Appl Microbiol Biot 98:7331-7347 doi:10.1007/s00253-014-5861-x

Gasser I, Vieira de Castro Junior J, Müller H, Berg G (2011) Lichen-associated bacteria antagonistic to phytopathogens and their potential to accumulate polyhydroxyalkanoates, in Pertot, I., Elad Y, Gessler, C and A. Cini (eds) Working Group "Biological Control of Fungal and Bacterial Plant Pathogens" IOBC WPRS BULLETIN V78 ISBN 978-92-9067-256-2 pp 375-379,

Golakoti T, Yoshida WY, Chaganty S, Moore RE (2001) Isolation and structure determination of nostocyclopeptides A1 and A2 from the terrestrial cyanobacterium Nostoc sp ATCC53789. J Nat Prod 64:54-59 doi:10.1021/np000316k

Gonzalez I, Ayuso-Sacido A, Anderson A, Genilloud O (2005) Actinomycetes isolated from lichens: Evaluation of their diversity and detection of biosynthetic gene sequences FEMS Microbiol Ecol 54:401-415 doi:10.1016/j.femsec.2005.05.004

Grube M, Blaha J (2003) On the phylogeny of some polyketide synthase genes in the lichenized genus Lecanora. Mycol Res 107:1419-1426 doi:10.1017/s0953756203008724

Grube M, Cardinale M, de Castro JV, Jr., Mueller H, Berg G (2009) Species-specific structural and functional diversity of bacterial communities in lichen symbioses. ISME J 3:1105-1115 doi:10.1038/ismej.2009.63 
Grube M, Cernava T, Soh J, Fuchs S, Aschenbrenner I, Lassek C, Wegner U, Becher D, Riedel K, Sensen CW, Berg G (2015) Exploring functional contexts of symbiotic sustain within lichen-associated bacteria by comparative omics. ISME Journal 9:412424 doi:10.1038/ismej.2014.138

Grube M, Koeberl M, Lackner S, Berg C, Berg G (2012) Host-parasite interaction and microbiome response: effects of fungal infections on the bacterial community of the Alpine lichen Solorina crocea FEMS Microbiol Ecol 82:472-481 doi:10.1111/j.15746941.2012.01425.x

Hamada M, Yamamura H, Komukai C, Tamura T, Suzuki K-i, Hayakawa M (2012) Luteimicrobium album sp nov., a novel actinobacterium isolated from a lichen collected in Japan, and emended description of the genus Luteimicrobium. J Antibiot 65:427-431 doi:10.1038/ja.2012.45

Hirsch CF, Liesch JM, Michael J. Salvatore, Schwartz RE, Sesin DF (1990) Antifungal Fermentation Product and Method. USA Patent 4946835,

Hodkinson BP, Gottel NR, Schadt CW, Lutzoni F (2012) Photoautotrophic symbiont and geography are major factors affecting highly structured and diverse bacterial communities in the lichen microbiome. Environ Microbiol 14:147-161 doi:10.1111/j.1462-2920.2011.02560.x

Hodkinson BP, Lutzoni F (2009) A microbiotic survey of lichen-associated bacteria reveals a new lineage from the Rhizobiales. Symbiosis 49:163-180 doi:10.1007/s13199-0090049-3

Honegger R (2000) Great Discoveries in bryology and lichenology - Simon Schwendener (1829-1919) and the Dual Hypothesis of Lichens. Bryologist 103:307-313 doi:10.1639/0007-2745(2000)103[0307:SSATDH]2.0.CO;2

Huneck S, Yoshimura I (1996) Identification of lichen substances. 1st edn. Springer-Verlag, Berlin

Jakobi M, Winkelmann G, Kaiser D, Kempter C, Jung G, Berg G, Bahl H (1996) Maltophilin: A new antifungal compound produced by Stenotrophomonas maltophilia R3089. J Antibiot 49:1101-1104

Kaasalainen U, Fewer DP, Jokela J, Wahlsten M, Sivonen K, Rikkinen J (2013) Lichen species identity and diversity of cyanobacterial toxins in symbiosis. New Phytol 198:647-651 doi:10.1111/nph.12215

Kampa A, Gagunashvili AN, Gulder TAM, Morinaka BI, Daolio C, Godejohann M, Miao VPW, Piel J, Andresson OS (2013) Metagenomic natural product discovery in lichen provides evidence for a family of biosynthetic pathways in diverse symbioses. Proc Natl Acad Sci U S A 110:E3129-E3137 doi:10.1073/pnas.1305867110

Kim M-K, Park H, Oh T-J (2013) Antimicrobial properties of the bacterial associates of the Arctic lichen Stereocaulon sp. Afr J Microbiol Res 7: 3651-3657.

Kim MK, Park H, Oh TJ (2014) Antibacterial and Antioxidant Capacity of Polar Microorganisms Isolated from Arctic Lichen Ochrolechia sp. Pol J Microbiol 63:317322

Lang E, Swiderski J, Stackebrandt E, Schumann P, Sproeer C, Sahin N (2007) Herminiimonas saxobsidens sp nov., isolated from a lichen-colonized rock. Int J Syst Evol Micr 57:2618-2622 doi:10.1099/ijs.0.65163-0

Lavallee V (2011) Antipain and its Analogues, Natural Product Inhibitors of Cathepsin K Isolated from Streptomyces. MSc., The University of British Columbia

Lee D-H, Hur JS, Kahng H-Y (2013) Sphingobacterium cladoniae sp nov., isolated from lichen, Cladonia sp., and emended description of Sphingobacterium siyangense. Int J Syst Evol Micr 63:755-760 doi:10.1099/ijs.0.038844-0 
Lee H, Shin SC, Lee J, Kim SJ, Kim B-K, Hong SG, Kim EH, Park H (2012a) Genome Sequence of Sphingomonas sp Strain PAMC 26621, an Arctic-Lichen-Associated Bacterium Isolated from a Cetraria sp. J Bacteriol 194:3030-3030 doi:10.1128/jb.00395-12

Lee J, Shin SC, Kim SJ, Kim B-K, Hong SG, Kim EH, Park H, Lee H (2012c) Draft Genome Sequence of a Sphingomonas sp., an Endosymbiotic Bacterium Isolated from an Arctic Lichen Umbilicaria sp. J Bacteriol 194:3010-3011 doi:10.1128/jb.00360-12

Lee YM, Kim EH, Lee HK, Hong SG (2014) Biodiversity and physiological characteristics of Antarctic and Arctic lichens-associated bacteria World J Microb Biot 30:2711-2721 doi:10.1007/s11274-014-1695-z

Li B, Xie C-H, Yokota A (2007) Nocardioides exalbidus sp. nov., a novel actinomycete isolated from lichen in Izu-Oshima Island, Japan. Actinomycetologica 21:22-26 doi:10.3209/saj.SAJ210103

Liba CM, Ferrara FIS, Manfio GP, Fantinatti-Garboggini F, Albuquerque RC, Pavan C, Ramos PL, Moreira-Filho CA, Barbosa HR (2006) Nitrogen-fixing chemoorganotrophic bacteria isolated from cyanobacteria-deprived lichens and their ability to solubilize phosphate and to release amino acids and phytohormones. J Appl Microbiol 101:1076-1086 doi:10.1111/j.1365-2672.2006.03010.x

Magarvey NA, Beck ZQ, Golakoti T, Ding Y, Huber U, Hemscheidt TK, Abelson D, Moore RE, Sherman DH (2006) Biosynthetic characterization and chemoenzymatic assembly of the cryptophycins. Potent anticancer agents from Nostoc cyanobionts. ACS Chem Biol 1:766-779 doi:10.1021/cb6004307

Mannisto MK, Tiirola M, McConnell J, Haggblom MM (2010) Mucilaginibacter frigoritolerans sp nov., Mucilaginibacter lappiensis sp nov and Mucilaginibacter mallensis sp nov., isolated from soil and lichen samples. Int J Syst Evol Micr 60:28492856 doi:10.1099/ijs.0.019364-0

McCurdy HD (1971) Studies on the Taxonomy of the Myxobacterales: IV. Melittangium. Int J Syst Evol Micr 21:50-54 doi:doi:10.1099/00207713-21-1-50

Molnár K, Farkas E (2010) Current Results on Biological Activities of Lichen Secondary Metabolites: a Review. Z Naturforsch vol 65. doi:10.1515/znc-2010-3-401

Moore RE, Patterson GML (1997) Method for producing Cryptocins by cultivating a Nostoc sp. USA Patent 5,945,315,

Motohashi K, Takagi M, Yamamura H, Hayakawa M, Shin-ya K (2010) A new angucycline and a new butenolide isolated from lichen-derived Streptomyces spp J Antibiot 63:545-548 doi:10.1038/ja.2010.94

Muggia L, Grube M (2010) Type III polyketide synthases in lichen mycobionts. Fungal Biol 114:379-385 doi:10.1016/j.funbio.2010.03.001

Muggia L, Klug B, Berg G, Grube M (2013) Localization of bacteria in lichens from Alpine soil crusts by fluorescence in situ hybridization. Appl Soil Ecol 68:20-25 doi:10.1016/j.apsoil.2013.03.008

Mushegian AA, Peterson CN, Baker CCM, Pringle A (2011) Bacterial Diversity across Individual Lichens. Appl Environ Microb 77:4249-4252 doi:10.1128/aem.02850-10

Niedermeyer THJ, Daily A, Swiatecka-Hagenbruch M, Moscow JA (2014) Selectivity and Potency of Microcystin Congeners against OATP1B1 and OATP1B3 Expressing Cancer Cells Plos One 9 doi:10.1371/journal.pone.0091476

Ochi K, Hosaka T (2013) New strategies for drug discovery: activation of silent or weakly expressed microbial gene clusters Appl Microbiol Biot 97:87-98 doi:10.1007/s00253012-4551-9

Oksanen I, Jokela J, Fewer DP, Wahlsten M, Rikkinen J, Sivonen K (2004) Discovery of rare and highly toxic microcystins from lichen-associated cyanobacterium Nostoc sp strain 
IO-102-I. Appl Environ Microb 70:5756-5763 doi:10.1128/aem.70.10.57565763.2004

Pankratov TA (2012) Acidobacteria in microbial communities of the bog and tundra lichens Microbiology 81:51-58 doi:10.1134/S0026261711060166

Parrot D, Antony-Babu S, Intertaglia L, Grube M, Tomasi S, Suzuki M (2015) Littoral lichens as a novel source of potentially bioactive Actinobacteria. Sci Rep in press

Reichenbach H (1999) The ecology of the myxobacteria Environ Microbiol 1:15-21 doi:10.1046/j.1462-2920.1999.00016.x

Rikkinen J (1995) What's behind the pretty colours?: a study on the photobiology of lichens. Finnish Bryological Society, ISBN: 951-96475-3-8

Robinson C (1999) The genetics of industrial microorganisms: the first half century Trends Biotechnol 17:178-181

Schendener S (1860) Untersuchunger über des Flechtentallus. In: Nägeli C (ed) Beiträge zur Wissenchaftlichen Botanik, vol 2. vol 2. Wilhelm Engelman, Leipizg, pp 109-186

Schneider T, Schmid E, de Castro JV Jr, Cardinale M, Eberl L, Grube M, Berg G, Riedel K. (2011). Structure and function of the symbiosis partners of the lung lichen (Lobaria pulmonaria L. Hoffm.) analyzed by metaproteomics. Proteomics. 11:2752-6. d

Schmitt I, Kautz S, Lumbsch HT (2008) 6-MSAS-like polyketide synthase genes occur in lichenized ascomycetes Mycol Res 112:289-296 doi:10.1016/j.mycres.2007.08.023

Selbmann L, Zucconi L, Ruisi S, Grube M, Cardinale M, Onofri S (2010) Culturable bacteria associated with Antarctic lichens: affiliation and psychrotolerance. Polar Biol 33:7183 doi:10.1007/s00300-009-0686-2

Shin SC, Ahn DH, Lee JK, Kim SJ, Hong SG, Kim EH, Park H (2012) Genome Sequence of Sphingomonas sp Strain PAMC 26605, Isolated from Arctic Lichen (Ochrolechia sp.) . J Bacteriol 194:1607-1607 doi:10.1128/jb.00004-12

Shrestha G, St Clair LL (2013) Lichens: a promising source of antibiotic and anticancer drugs. Phytochem Rev 12:229-244 doi:10.1007/s11101-013-9283-7

Shukla V, Joshi GP, Rawat MSM (2010) Lichens as a potential natural source of bioactive compounds: a review. Phytochem Rev 9:303-314 doi:10.1007/s11101-010-9189-6

Sigurbjornsdottir MA, Andresson OS, Vilhelmsson O (2015) Analysis of the Peltigera membranacea metagenome indicates that lichen-associated bacteria are involved in phosphate solubilization. Microbiology (SGM) 161:989-996

doi:10.1099/mic.0.000069

Sigurbjornsdottir MA, Heidmarsson S, Jonsdottir AR, Vilhelmsson O (2014) Novel bacteria associated with Arctic seashore lichens have potential roles in nutrient scavenging Can J Microbiol 60:307-317 doi:10.1139/cjm-2013-0888

Singh SB, Garrity GM, Genillourd O, Lingham RB, Martin I, Nallin-Omstead M, Silverman KC, Zink DL (1997) Inhibitor compounds of farnesyl-protein transferase and chemotherapeutic compositions containing the same, produced by strain ATCC 55532. USA Patent 5,627,057,

Stocker-Woergoetter E (2008) Metabolic diversity of lichen-forming ascomycetous fungi: culturing, polyketide and shikimate metabolite production, and PKS genes. Nat Prod Rep 25:188-190 doi:10.1039/b606983p

Subramani R, Aalbersberg W (2013) Culturable rare Actinomycetes: diversity, isolation and marine natural product discovery. Appl Microbiol Biot 97:9291-9321 doi:10.1007/s00253-013-5229-7

Taylor TN, Hass H, Remy W, Kerp H (1995) The oldest fossil lichen. Nature 378:244-244 doi:10.1038/378244a0

Thaxter R (1892) On the Myxobacteriaceae a New Order of Schizomycetes. Bot Gaz 17:389406 doi:10.2307/2464109 
Uphof JCT (1925) Purple bacteria as symbionts of a lichen Science 61:67-67 doi:10.1126/science.61.1568.67

Verma S, Miles D, Gianni L, Krop IE, Welslau M, Baselga J, Pegram M, Oh DY, Dieras V, Guardino E, Fang L, Lu MW, Olsen S, Blackwell K, Grp ES (2012) Trastuzumab Emtansine for HER2-Positive Advanced Breast Cancer New England Journal of Medicine 367:1783-1791 doi:10.1056/NEJMoa1209124

Woolhouse, M., and Farrar, J. (2014) Policy: An intergovernmental panel on antimicrobial resistance. Nature 509: 555-557.

Williams DE, Davies J, Patrick BO, Bottriell H, Tarling T, Roberge M, Andersen RJ (2008) Cladoniamides A-G, tryptophan-derived alkaloids produced in culture by Streptomyces uncialis. Org Lett 10:3501-3504 doi:10.1021/ol801274c

Wilson MC, Mori T, Ruckert C, Uria AR, Helf MJ, Takada K, Gernert C, Steffens UAE, Heycke N, Schmitt S, Rinke C, Helfrich EJN, Brachmann AO, Gurgui C, Wakimoto T, Kracht M, Crusemann M, Hentschel U, Abe I, Matsunaga S, Kalinowski J, Takeyama H, Piel J (2014) An environmental bacterial taxon with a large and distinct metabolic repertoire. Nature 506:58-+ doi:10.1038/nature12959

Yamamura H, Ashizawa H, Nakagawa Y, Hamada M, Ishida Y, Otoguro M, Tamura T, Hayakawa M (2011a) Actinomycetospora iriomotensis sp nov., a novel actinomycete isolated from a lichen sample. J Antibiot 64:289-292 doi:10.1038/ja.2011.15

Yamamura H, Ashizawa H, Nakagawa Y, Hamada M, Ishida Y, Otoguro M, Tamura T, Hayakawa M (2011b) Actinomycetospora rishiriensis sp nov., isolated from a lichen. Int J Syst Evol Micr 61:2621-2625 doi:10.1099/ijs.0.028753-0

Yang XM, Shimizu YZ, Steiner JR, Clardy J (1993) Nostoclide I and II, extracellular metabolites from a symbiotic cyanobacterium, Nostoc sp, from the lichen Peltigera canina. Tetrahedron Lett 34:761-764 doi:10.1016/0040-4039(93)89005-b

Yasuda Y, Kaleta J, Bromme D (2005) The role of cathepsins in osteoporosis and arthritis: Rationale for the design of new therapeutics. Adv Drug Deliver Rev 57:973-993 doi:10.1016/j.addr.2004.12.013

Yim G, Wang HH, Davies J (2007) Antibiotics as signalling molecules. Philos Trans R Soc Lond B Biol Sci 362:1195-1200 doi:10.1098/rstb.2007.2044

Yoon V, Nodwell JR (2014) Activating secondary metabolism with stress and chemicals. J Ind Microbiol Biotechnol 41:415-424 doi:10.1007/s10295-013-1387-y

Zachow C, Müller H, Tilcher R, Donat C, Berg G (2013) Catch the Best: Novel screening strategy to select stress protecting agents for crop plants. Agronomy 3: 794-815.

Zhang LP, Wang HY, Fang XM, Stackebrandt E, Ding YB (2003) Improved methods of isolation and purification of myxobacteria and development of fruiting body formation of two strains. J Microbiol Meth 54:21-27 doi:10.1016/s0167-7012(02)00257-9 
<smiles>CCC(CC(C)C(=O)O)C(=O)CC/C(C)=C/C(C)C/C(C)=C/C(C)C(O)C(C)CCC(CCCC/C=C/C(C)CCC(C)OC(=O)CC(CC(=O)O)C(=O)O)OC(=O)CC(CC(=O)O)CC(=O)O</smiles><smiles>CNC(=O)[C@@]1(O)Cn2c(c(OC)c3cc(Cl)ccc32)-c2[nH]c3ccc(Cl)cc3c21</smiles><smiles>O=C1c2ccc(Cl)c(O)c2C(=O)c2c1ccc1c2C(=O)C2C(C1O)C2(Cl)Cl</smiles>

3<smiles>[3H]C1CC(=O)C2C(CC3CC(CC)C(C)C32)C1C/C=C\C(=O)NCCC(O)C1NC(=O)C(C(=O)O)=C1O</smiles><smiles>C=C1OC(O)(CO)C=C1C=CCCCC</smiles>
5<smiles>OC1COC(O)CC(O)C1</smiles><smiles>CC[C@]1(O)CCc2c(O)c3c(c(O)c2[C@@H]1OC1CC(C(=O)N(C)C)C(C)CO1)C(=O)c1c(O)cccc1C3=O</smiles><smiles>Cc1ccccc1</smiles><smiles>COc1ccc(C[C@H](NC(=O)/C=C/C[C@H](OC(=O)C(CC(C)C)OC(=O)[C@H](C)CNC(=O)[C@H]2CO2)C(C)C)C(=O)O)cc1Cl</smiles><smiles>C=C1C[C@](OC)([C@H](O)C(=O)N/C=C/[C@H](CO)[C@@H](O)[C@H](C)C(=O)N2CCC[C@H]2[C@H](O)CC(N)=O)O[C@H](C)[C@@H]1C</smiles>

Figure 1. Structures of some molecules produced by lichen associated bacteria (1) actinoplanic acid B, (2) uncialamycin, (3) cladoniamide G (4) JBIR-88 (5) JBIR-89 (6) cosmomycin B (7) maltophilin (8) cryptophycin 1 (9) nosperin 
Table 1. Bacterial strains isolated from lichens that 1) are officially described and/or 2) have a fully sequenced genome and/or 3) produced molecules that have been identified

\begin{tabular}{|c|c|c|c|c|c|}
\hline Strain & Phylum or Class - Famlly & Location, Lichen & $\begin{array}{l}\text { Isolation } \\
\text { Medium }\end{array}$ & $\begin{array}{l}\text { Nalidixic } \\
\text { Acid }\end{array}$ & Reference \\
\hline $\begin{array}{l}\text { Corallococcus sp. } \\
\text { ATCC } 25944\end{array}$ & $\begin{array}{l}\text { Deltaproteobacteria - } \\
\text { Myxococcaceae }\end{array}$ & n.r. & n.r. & no & McCurdy et al, 1971 \\
\hline $\begin{array}{l}\text { Actinoplanes sp. } \\
\text { ATCC } 55532\end{array}$ & $\begin{array}{l}\text { Actinobacteria - } \\
\text { Actinoplanacee }\end{array}$ & $\begin{array}{l}\text { Spain, Madrid } \\
\text { Unidentified }\end{array}$ & ISP3 & no & Singh et al 1997 \\
\hline $\begin{array}{l}\text { Streptomyces } \\
\text { uncialis "ex Julian } \\
\text { Davis et al." }\end{array}$ & $\begin{array}{l}\text { Actinobacteria - } \\
\text { Streptomycetaceae }\end{array}$ & $\begin{array}{l}\text { Canada, British Columbia } \\
\text { Surface of Cladonia uncialis }\end{array}$ & n.r. & no & Davies et al. 2005 \\
\hline $\begin{array}{l}\text { Herminiimonas } \\
\text { saxobsidens NS11 }\end{array}$ & $\begin{array}{l}\text { Betaproteobacteria - } \\
\text { Oxalobacteraceae }\end{array}$ & $\begin{array}{l}\text { Turkey, Mugla } \\
\text { Lichen-Rock interface }\end{array}$ & $\begin{array}{l}\text { Potassium } \\
\text { Oxalate }\end{array}$ & no & Lang et al. 2007 \\
\hline $\begin{array}{l}\text { Nocardioides } \\
\text { exalbidus RC } 825\end{array}$ & $\begin{array}{l}\text { Actinobacteria - } \\
\text { Nocardioidaceae }\end{array}$ & $\begin{array}{l}\text { Japan, Izu Oshima Island } \\
\text { unidentified }\end{array}$ & IAM-A1 & no & Li et al 2007 \\
\hline $\begin{array}{l}\text { Schumannella } \\
\text { luteola KHIA }\end{array}$ & $\begin{array}{l}\text { Actinobacteria - } \\
\text { Microbacteriaceae }\end{array}$ & $\begin{array}{l}\text { Japan, Tokyo } \\
\text { unidentified }\end{array}$ & $\begin{array}{l}\text { Modified } \\
\text { Dettmer }\end{array}$ & no & An et al 2008 \\
\hline $\begin{array}{l}\text { Leifsonia lichenia } \\
2 \mathrm{Sb}\end{array}$ & $\begin{array}{l}\text { Actinobacteria - } \\
\text { Microbacteriacee }\end{array}$ & $\begin{array}{l}\text { Japan, Tokyo } \\
\text { unidentified }\end{array}$ & $\begin{array}{l}\text { Modified } \\
\text { Dettmer }\end{array}$ & no & An et al 2009 \\
\hline $\begin{array}{l}\text { Mucilaginibacter } \\
\text { lappiensis ANJLI2 }\end{array}$ & $\begin{array}{l}\text { Bacteroidetes- } \\
\text { Sphingobacteriaceae }\end{array}$ & $\begin{array}{l}\text { Finland, Lapland } \\
\text { Decaying Lichen }\end{array}$ & Lichenin & no & Mänistö et al 2010 \\
\hline $\begin{array}{l}\text { Streptomyces sp. } \\
\text { RI104-LiC106 }\end{array}$ & $\begin{array}{l}\text { Actinobacteria - } \\
\text { Streptomycetaceae }\end{array}$ & $\begin{array}{l}\text { Japan, Rishiri Island } \\
\text { unidentified }\end{array}$ & HV agar & yes & Motohashi et al 2010 \\
\hline
\end{tabular}


Streptomyces sp.

RI104-LiB101

Actinobacteria -

Streptomycetaceae

Streptomyces sp. L- Actinobacteria -

91-3

Streptomycetaceae

Frondihabitans

cladoniiphilus

CafT13

Actinomycetospora iriomotensis IR73-

Li102

Actinomycetospora rishiriensis RI109-

Li102

Sphingomonas sp

PAMC26605

\section{Sphingomonas sp} PAMC26621

Sphingomonas sp PAMC26617

Sphingobacterium cladoniae No.6

Luteimicrobium album RI148-Li105
Actinobacteria -

Microbacteriaceae

Actinobacteria -

Pseudonocardiaceae

Actinobacteria -

Pseudonocardiaceae

Alphaproteobacteria Sphingomonadales

Alphaproteobacteria Sphingomonadales

Alphaproteobacteria Sphingomonadales

Bacteroidetes-

Sphingobacteriaceae

Actinobacteria -

Promicromonosporaceae
Japan, Rishiri Island

Motohashi et al 2010

unidentified

Canada, British Columbia

Unidentified

Austrian alps

Japan, Iriomote Island

crustose unidentified

\section{humic}

yes

acid

vitamin

agar

Japan, Rishiri Island

unidentified

humic

acid

vitamin

agar

Arctic Norway (Svalbard)

Ochrolechia sp.

Arctic Norway (Svalbard)

Cetaria sp.

Arctic Norway (Svalbard)

Umbilicaria sp.

Korea, Geogeum Island

Cladonia sp

Japan Rishiri Island

foliaceous unidentified n.r.

n.r.

n.r.
Lavallée 2011

Cardinale et al. 2011

Yamamura et al.

2011a

Yamamura et al.

2011b

Shin et al 2012

Lee et al 2012a

Lee et al 2012c

Lee et al 2013

Hamada et al 2013 


\begin{tabular}{|c|c|c|c|c|c|}
\hline $\begin{array}{l}\text { Streptomyces } \\
\text { cyaneofuscatus } \\
\text { T178 }\end{array}$ & $\begin{array}{l}\text { Actinobacteria - } \\
\text { Streptomycetaceae }\end{array}$ & $\begin{array}{l}\text { Spain, Muniellos } \\
\text { Unidentified }\end{array}$ & TSA & yes & Braña et al 2015 \\
\hline $\begin{array}{l}\text { Streptomyces } \\
\text { cyaneofuscatus T35 }\end{array}$ & $\begin{array}{l}\text { Actinobacteria - } \\
\text { Streptomycetaceae }\end{array}$ & $\begin{array}{l}\text { Spain, La Vecilla } \\
\text { Unidentified }\end{array}$ & TSA & yes & Braña et al 2015 \\
\hline $\begin{array}{l}\text { Streptomyces } \\
\text { cyaneofuscatus } \\
\text { T140 }\end{array}$ & $\begin{array}{l}\text { Actinobacteria - } \\
\text { Streptomycetaceae }\end{array}$ & $\begin{array}{l}\text { Spain, Cuntis } \\
\text { Unidentified }\end{array}$ & TSA & yes & Braña et al 2015 \\
\hline $\begin{array}{l}\text { Streptomyces } \\
\text { cyaneofuscatus } \\
\text { T163 }\end{array}$ & $\begin{array}{l}\text { Actinobacteria - } \\
\text { Streptomycetaceae }\end{array}$ & $\begin{array}{l}\text { Portugal, Guimarães } \\
\text { Unidentified }\end{array}$ & TSA & yes & Braña et al 2015 \\
\hline
\end{tabular}


Table 2. A list of studies that surveyed the diversity of microbial isolates associated with lichens

\begin{tabular}{|c|c|c|c|c|c|}
\hline Lichen species & Lichen origin & $\begin{array}{l}\text { target of } \\
\text { isolation }\end{array}$ & Medium & $\begin{array}{l}\text { Potentially interesting families, } \\
\text { activities or others caracteristics of } \\
\text { biotechnological interest }\end{array}$ & Reference \\
\hline Not identified & $\begin{array}{l}\text { Sitka and Kodiak, } \\
\text { Alaska Hawaii and } \\
\text { Reunion Islands }\end{array}$ & Biotechnology & $\begin{array}{l}\text { soil } \\
\text { extract } \\
\text { agar, } \\
\text { humic } \\
\text { acid agar } \\
\text { and } \\
\text { glycerol } \\
\text { asparagi } \\
\text { ne agar }\end{array}$ & $\begin{array}{l}\text { Streptomycetaceae, } \\
\text { Micromonosporaceae, } \\
\text { Pseudonocardiaceae, } \\
\text { Thermomonosporaceae. } \\
\text { Antimicrobial activity, Genes } \\
\text { involved in biosynthesis of } \\
\text { secondary metabolites. }\end{array}$ & $\begin{array}{l}\text { Gonzalez et al. } \\
2005\end{array}$ \\
\hline $\begin{array}{l}\text { Cladonia digitata, C. } \\
\text { rangiferina, C coniocracea, } \\
\text { C. pyxidata, C. coccifera, } \\
\text { Pseudoevernia furfuracea, } \\
\text { Hypogminia physodes, } \\
\text { Rocella phycopsis*, R. } \\
\text { fuciformis* }\end{array}$ & $\begin{array}{l}\text { Styria, Austria } \\
\text { and Normandy, } \\
\text { France* }\end{array}$ & $\begin{array}{l}\text { Untargeted, } \\
\text { Diazotrophs }\end{array}$ & $\begin{array}{l}\text { TYE, } \\
\text { Sugar- } \\
\text { rich N } \\
\text { free }\end{array}$ & $\begin{array}{l}\text { Bacillaceae, Paenibacillaceae, } \\
\text { Burkholderiaceae, } \\
\text { Micromonosporaceae, } \\
\text { Streptomycetaceae, } \\
\text { Streptosporangiaceae }\end{array}$ & $\begin{array}{l}\text { Cardinale et al. } \\
2006\end{array}$ \\
\hline $\begin{array}{l}\text { Canoparmelia caroliniana, } \\
\text { Canoparmelia crozalsiana, } \\
\text { Canoparmelia texana, } \\
\text { Parmotrema sancti-angeli } \\
\text { Parmotrema tinctorum }\end{array}$ & Rain Forest, Brazil & Diazotrophs & $\begin{array}{l}\mathrm{N} \text {-free } \\
\mathrm{NFb}\end{array}$ & Pseudomonadaceae & Liba et al. 2006 \\
\hline
\end{tabular}


Cladonia arbuscula, Lecanora polytropa, Umbilicaria cylindrica

Lecanora fuscobrunnea, Umbilicaria decussata,

Usnea antarctica,

Xanthoria elegans

\section{Cladonia sp. Cladonia} rangiferina

Ochrolechia sp

Usnea sp., Cladonia

borealis, Psoroma sp.,

Stereocaulon sp.,

Umbilicaria sp., Cetraria

sp., Ochrolechia sp.

Lecanora helicopis,

Verrucaria ceuthocarpa,

Hydropunctaria

maura, Caloplaca

verruculifera wind-swept heath Untargeted above the tree

line Austria

\section{Antarctic}

Psychrophiles

TYE

Spagnun Bog,

Tundra; Russia

Arctic

Antarctic and

Arctic

Northern Iceland Untargeted seashore Crag,

R2A

Acidobacteria

M3

Antimicrobial
Bacillaceae, Paenibacillaceae

Burkholderiaceae. Chitinolytic,

glucanolytic, and proteolytic

activity, hormone production

(indole-3-acetic acid). Antagonistic

activity

Pseudomonadaceae, Bacillaceae

Lichen

None, as only Acidobacteria isolated

extract, described

MY/R2A

Burkholderiaceae,

Sphingomonadaceae. Antimicrobial, Antioxidant, Prod. Carotenoids

R2A,

ISP4, MY Paenibacillaceae, Burkholderiaceae, Pseudomonadaceae; Extracellular

proteases, Lipases

Marine Streptomycetaceae, Bacillaceae

Agar
Selbman et al

Grube et al.

Pankratov

2012

Kim et al. 2014

Lee et al. 2014

Sigurbjörnsdòti r et al. 2014 
Bacillaceae, Paenibacillaceae,

\section{Burkholderiaceae,}

ISP2

Pseudomonadaceae,

Nocardioidaceae,

Xanhtomonadaceae

Antagonisitic activity, Volatile

Organic Compound production,

Spermidine production, hydrogen

cyanide production

Lichina confinis, Lichina

pygmaea, Rocella

fuciformis, Collema

Marine, France;

Riparian, Austria

Littoral

Lichens;

Actinobacteria

Marine

Agar,

Bacillaceae, Pseudomonadaceae,

Nocardioidaceae,

AIA,ISP2 Promicromonosporaceae,

with Pseudonocardiaceae,

Nalidixic Streptomycetaceae. Pks I and Pks

acid

\section{auriformis}

II genes.
Parrot et al.

Cernava et al

2015a Cernava

et al. 2015b

2015 
Table 3. Cyanobacteria strains isolated from lichens with characterized secondary metabolites

\begin{tabular}{lllll}
\multicolumn{1}{c}{ Strain } & \multicolumn{1}{c}{ Lichen species } & \multicolumn{1}{c}{ Lichen origin } & Metabolites Described & Reference \\
\hline Nostoc sp. ATCC 53789 & Not described & $\begin{array}{l}\text { Lichen, Arron Island, } \\
\text { Scotland }\end{array}$ & Cryptophycin 1 & Hisrsch et al 1990 \\
Nostoc sp. & Peltigera canina & Not reported & Nostoclide I and II & Yang et al 1993 \\
Nostoc sp. ATCC 53789 & Not described & $\begin{array}{l}\text { Lichen, Arron Island, } \\
\text { Scotland }\end{array}$ & Nostocyclopeptide A1 and A2 & Golakoti et al 2001 \\
Nostoc sp. IO-102-I & Pannaria pezizoides & Rock Southern & $\begin{array}{l}\text { [ADMAdda5]microcystin-LR } \\
\text { [DMAdda5]microcystin-LR }\end{array}$ & Oksanen et al. 2004 \\
& & Finland & [D-Asp3,ADMAdda5]microcystin- \\
& & & LR [ADMAdda5]-XR type variants & Nosperin
\end{tabular}


Table 4. Cultivation independent studies broadly targeting the diversity of lichen associated bacteria

\begin{tabular}{|c|c|c|c|c|c|}
\hline Lichen species & Lichen origin & $\begin{array}{l}\text { Techniques } \\
\text { applied }\end{array}$ & $\begin{array}{c}\text { Phyla/Class described, average and } \\
\text { range of percentage of Totalף, } \\
\text { Prokaryotes, Bacteria§ }\end{array}$ & $\begin{array}{l}\text { Potentially interesting } \\
\text { families*, activities or others } \\
\text { caracteristics of } \\
\text { biotechnological interest }\end{array}$ & Reference \\
\hline $\begin{array}{l}\text { Cladonia digitata, C. } \\
\text { rangiferina, C. } \\
\text { coniocracea, C. } \\
\text { pyxidata, C. coccifera, } \\
\text { Pseudevernia } \\
\text { furfuracea, } \\
\text { Hypogymnia } \\
\text { physodes, Roccella } \\
\text { phycopsis*, R. } \\
\text { fuciformis* }\end{array}$ & $\begin{array}{l}\text { Styria, Austria } \\
\text { and Normandy, } \\
\text { France* }\end{array}$ & $\begin{array}{l}\text { ITS } \\
\text { fingerprinti } \\
\text { ng, } \\
\text { Sequencin } \\
\mathrm{g} \text { of bands }\end{array}$ & $\begin{array}{l}\text { Gammaproteobacteria } \\
\text { Actinobacteria } \\
\text { Betaproteobacteria }\end{array}$ & Bacillaceae & $\begin{array}{l}\text { Cardinale et al } \\
2006\end{array}$ \\
\hline Cladonia arbuscula & Styria, Austria & $\begin{array}{l}\text { FISH, } \\
\text { SSCP }\end{array}$ & $\begin{array}{l}\text { Alphaproteobacteria } 75 \% \\
\text { Actinobacteria } 6 \% \\
\text { Betaproteobacteria } 4 \%\end{array}$ & Not described & $\begin{array}{l}\text { Cardinale et al } \\
2008\end{array}$ \\
\hline $\begin{array}{l}\text { Cladonia cristatella, C. } \\
\text { cryptochlorophaea, C. } \\
\text { cf. sobolescens, C. } \\
\text { peziziformis, C. } \\
\text { subtenuis, } \\
\text { Flavoparmelia } \\
\text { caperata, Parmotrema } \\
\text { perforatum, Peltigera } \\
\text { phyllidiosa, Lasallia } \\
\text { pensylvanica, } \\
\text { Umbilicaria }\end{array}$ & $\begin{array}{l}\text { Virginia and N. } \\
\text { Carolina, USA }\end{array}$ & $\begin{array}{l}\text { Direct } \\
\text { Sanger } \\
\text { sequencing } \\
\text { of PCR } \\
\text { products } \\
\text { using } \\
\text { universal } \\
\text { primers } \\
\text { (RHAPSA- } \\
\text { D) }\end{array}$ & $\begin{array}{l}\text { Alphaproteobacteria } \\
\text { Acidobacteria } \\
\text { Gammaproteobacteria }\end{array}$ & None & $\begin{array}{l}\text { Hodkinson and } \\
\text { Lutzoni } 2009\end{array}$ \\
\hline
\end{tabular}


Cladonia arbuscula, Lecanora polytropa, Umbilicaria cylindrica

Xanthoparmelia plittii, $X$. somloënsis

\section{Styria, Austria} FISH,
SSCP

Alphaproteobacteria 45-75\%

Actinobacteria 6\%

Betaproteobacteria 4\%

Massachusetts, PyroUSA
Alphaproteobacteria (30-60\% §) sequencing Acidobacteria ( $17 \% \S)$

of $16 \mathrm{~S}$

rRNAs
Bacteoidetes + Gammaproteobacteria + Deltaproteobacteria + Fibrobacteres $(<2 \% \S)$
Burkholderiaceae ${ }^{\mathrm{a}}$,

Pseudomonadaceae ${ }^{a}$

Not described

Mushegian et al 2011 
Parmelia sulcata,

Rhizoplaca

chrysoleuca,

Umbilicaria americana,

Umbilicaria phaea
Colorado, USA

Pyro-

sequencing

of $16 \mathrm{~S}$

rRNAs

Acidobacteriab $^{\mathrm{b}}(14 \% ; 4-25 \%)$

Gammaproteobacteria $^{\mathrm{b}}$ (8\%; 0-52\%)

Firmicutes $^{\mathrm{b}}(7 \% ; 1-13 \%)$

Verrucomicrobia ${ }^{\mathrm{b}}(6 \% ; 0-24 \%)$

Planctomycetes ${ }^{\mathrm{b}}(5 \% ; 1-10 \%)$

Actinobacteria $^{\mathrm{b}}(4 \% ; 0-10 \%)$

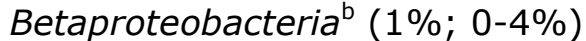

Bacteroidetes $^{\mathrm{b}}$ (3\%; 0-8\%)

Deltaproteobacteria ${ }^{\mathrm{b}}(1 \%$ 0-8\%)

\author{
DGGE, Alphaproteobacteria ${ }^{\mathrm{c}}(30 \% \S)$ \\ Clone Betaproteobacteria ${ }^{\mathrm{c}}(21 \% \S)$ \\ libraries \\ Actinobacteria $^{\mathrm{C}}(\sim 16 \% \S)$ \\ Acidobacteria $^{\mathrm{c}}(\sim 10 \% \S)$ \\ Cyanobacteria $^{\mathrm{c}}(8 \% \S)$ \\ Firmicutes ${ }^{\mathrm{c}}(7 \% \S)$ \\ Chloroflexic ${ }^{\mathrm{c}}(2 \% \S)$ \\ Bacteroidetes $^{\mathrm{c}}(1 \% \S)$
}

Lobaria pulmonaria

Styria, Austria

FISH,

SSCP

Alphaproteobacteria (47.3-93.9\%)

Alphaproteobacteria 15.5-80\%

Betaproteobacteria ${ }^{\mathrm{e}}$ 0-55\%

Gammaproteobacteria ${ }^{\mathrm{e}}$ 0-28\%

Actinobacteria $0-6 \%$

Lobaria pulmonaria

Lecanora polytropa,

Cladonia arbuscula,

SSCP
Paenibacillaceae ${ }^{\mathrm{b}}(1.6 \%)$

Micromonosporaceae ${ }^{\mathrm{b}}$

\section{(0.31\%)}

Kineosporiaceae $^{\mathrm{b}}(0.25 \%)$

Burkholderiaceae $^{\mathrm{b}}(0.18 \%)$

Myxococcales ${ }^{\mathrm{b}}(0.16 \%)$

Pseudonocardiaceae

(0.09\%)

Pseudomonadaceae ${ }^{\mathrm{b}}(0.03 \%)$

Actinomycetaceae $^{\mathrm{b}}(0.01 \%)$

\section{Burkholderiaceae}

Pseudomonadaceae ${ }^{\mathrm{c}}$

Nocardioidaceae ${ }^{c}$

Burkholderiaceae

Not described
Bates et al 2011

Umbilicaria cylindrica, 
Solorina crocea

Cladonia sp.,

Flavocetraria sp.,

Ophioparmasp.,

Umbilicaria sp., Usnea

sp., Dictyonema sp.,

Leptogium sp.,

Peltigera sp., Sticta

sp.

Arthrorhaphis

citrinella, Baeomyces

placophyllus, B. rufus, Icmadophila

ericetorum, Psora

decipiens Trapeliopsis

granulosa
Styria, Austria

Pyro-

sequencin

of $16 \mathrm{~S}$

rRNAs'

Cerro de la

Muerte, Costa

Rica

Alaska, USA

North Carolina,

USA

Pyro-

sequencing

of $16 \mathrm{~S}$

rRNAs ${ }^{+}$

Acidobacteria (42.4-66.4\%)

Proteobacteria (11-30\%)

Planctomycetes (7.2-25.2\%)

Actinobacteria (1.3-5.2\%)

Alphaproteobacteria $^{f}(60 \% ; 5-93 \% \S)$

Acidobacteria $^{f}(25 \% ; 1-92 \% \S)$

Betaproteobacteria $^{f}(5.0 \% ; 0-19 \% \S)$

Gammaproteobacteria $^{\mathrm{f}}$

(3.3\%; 0-9\%§)

Actinobacteria $^{f}(1.7 \% ; 0-13 \% \S)$

Verrucomicrobia $^{f}(1.5 \% ; 0-15 \% \S)$

Planctomycetes $^{f}(0.6 \% ; 0-22 \% \S)$

Bacteoidetes $^{f}(1.2 \% ; 0-6 \% \S)$

Deltaproteobacteria $^{f}(0.9 \% 0-6 \% \S)$

Firmicutes $^{f}(0.3 ; 0-2 \% \S)$

Styria, Austria

FISH
Alphaproteobacteria

Acidobacteria
Myxococcales

Grube et al 2012

Burkholderiaceae $(0.74 \%)$ Myxococcales ${ }^{f}(0.70 \%)$

Pseudomonadaceae ${ }^{f}(0.43 \%)$

Actinomycetaceae $(0.04 \%)$

Nocardioidaceae $(0.02 \%)$

Pseudonocardiaceae ${ }^{f}$,

(0.007\%)

Micromonosporaceae

$(0.007 \%)$

Kineoporiaceae $(0.005 \%)$

Not described

Muggia et al 2013
Hodkinson et al 2012 


\begin{tabular}{|c|c|c|c|c|c|}
\hline Rhizocarpon spp & $\begin{array}{l}\text { South Tyrol, } \\
\text { Italy }\end{array}$ & $\begin{array}{l}\text { DGGE, } 20 \\
\text { sequenced } \\
\text { bands }\end{array}$ & $\begin{array}{l}\text { Alphaproteobacteria } 11 \text { bands } \\
\text { Acidobacteria } 3 \text { bands } \\
\text { Bacteroidetes, Firmicutes, } \\
\text { Cyanobacteria and Actinobacteria } 1 \\
\text { band. }\end{array}$ & Not described & $\begin{array}{l}\text { Esposito et al } \\
2013\end{array}$ \\
\hline Lobaria pulmonaria & Styria, Austria & $\begin{array}{l}\text { Pyro- } \\
\text { sequencing } \\
\text { of rRNAs' } \\
\text { FISH }\end{array}$ & $\begin{array}{l}\text { Alphaproteobacteria }(35 \%) \\
\text { Bacteroidetes }^{9}(14 \%) \\
\text { Verrucomicrobia }^{9}(8 \%) \\
\text { Deltaproteobacteria }^{9}(7.5 \%) \\
\text { Actinobacteria }^{9}(12 \%) \\
\text { Betaproteobacteria }^{9}(2.7 \%) \\
\text { Gammaproteobacteria }^{9}(2.4 \%) \\
\text { Acidobacteria }^{9}(2.3 \%) \\
\text { Planctomycetes }^{9}(1.2 \%)\end{array}$ & $\begin{array}{l}\text { Myxococcales }^{\mathrm{g}}(6.9 \%) \\
\text { Pseudonocardiaceae }^{\mathrm{g}}(3.6 \%) \\
\text { Micromonosporaceae }^{\mathrm{g}}(1.3 \%) \\
\text { Kineoporiaceae }^{\mathrm{g}}(0.9 \%) \\
\text { Pseudomonadaceae }^{\mathrm{g}}(0.8 \%) \\
\text { Nocardioidaceae }^{\mathrm{g}}(0.8 \%) \\
\text { Burkholderiaceae }^{\mathrm{g}}(0.1 \%) \\
\text { Streptomycetaceae }^{\mathrm{g}}(0.1 \%)\end{array}$ & $\begin{array}{l}\text { Aschenbrenner } \\
\text { et al } 2014\end{array}$ \\
\hline $\begin{array}{l}\text { Peltigera } \\
\text { membranaceae }\end{array}$ & Iceland & $\begin{array}{l}\text { Shotgun } \\
\text { pyro- } \\
\text { sequencing } \\
\text { followed } \\
\text { by rRNA } \\
\text { analysis }\end{array}$ & $\begin{array}{l}\text { Alphaproteobacteria (40\%) } \\
\text { Bacteroidetes }(14 \%) \\
\text { Actinobacteria }(11 \%) \\
\text { Betaproteobacteria }(9 \%) \\
\text { Verrucomicrobia }(8 \%) \\
\text { Gammaproteobacteria }(5 \%) \\
\text { Deltaproteobacteria }(3 \%)\end{array}$ & $\begin{array}{l}\text { Nocardiaceae }^{\mathrm{h}} \\
\text { Myxococcales }^{\mathrm{h}} \\
\text { Burkholderiales }^{\mathrm{i}}\end{array}$ & $\begin{array}{l}\text { Sigurbjörnsdòttir } \\
\text { et al } 2015\end{array}$ \\
\hline
\end{tabular}

a. Estimated from PCR amplification with primers targeting these clades; b. Estimated from OTU table graciously provided by S. Bates; c Estimated from figure 3B in the reference; $d$. Estimated from PCR amplification with primers targeting this clade; e.Estimated from Figure 2A in the reference; f Estimated from the OTU table associated with the publication; g. Estimated from OTU table associated to the publication; h. Used as reference genomes i. based on blastx analysis of contigs

* Order in the case of Myxococcales +Cyanobacteria excluded 